\title{
THE HISTORY OF BIOCHEMISTRY
}

\author{
ВИНАХІДНИЦЬКА ДІЯЛЬНІСТЬ ВІДДІЛУ СТРУКТУРИ \\ І ФУНКЦЇ̈ БІЛКА ІНСТИТУТУ БІОХІМІЇ ІМ. О. В. ПАЛЛАДІНА \\ НАН УКРАЇНИ. ЧАСТИНА І. РОЗРОБЛЕННЯ ДІАГНОСТИЧНИХ \\ МЕТОДІВ ДЛЯ ВИЯВЛЕННЯ ПОРУШЕНЬ СИСТЕМИ ГЕМОСТАЗУ \\ I ХАРАКТЕРИСТИКА ОКРЕМИХ ФАКТОРІВ ЗСІДАННЯ КРОВІ
}

\author{
В. М. ДАНИЛОВА, Р. П. ВИНОГРАДОВА, М. В. ГРИГОР'СВА
}

Інститут біохімї ім. О. В. Палладіна НАН Украӥни, Київ;

e-mail:valdan@biochem.kiev.ua

$\mathrm{T}$ рохи історії... Фундатор Інституту біохімії, професор Олександр Володимирович Палладін (всесвітньо відомий вчений, академік АН СРСР, АН УРСР та багатьох іноземних академій) належав до тієї когорти вчених, які, відстоюючи необхідність теоретичного розвитку фундаментальних напрямів науки, вміли використовувати результати цих досліджень для практичних потреб економіки країни. Саме тому наукова тематика Інституту біохімії ім. О. В. Палладіна НАН України з моменту його заснування завжди носила високотеоретичний характер, але разом 3 тим також була пов'язана 3 життям країни і спрямована на одночасне вирішення практичних завдань медицини, харчової і легкої промисловості, а також сільського господарства, тобто спрямована на благо Людини.

Ці роботи вже в довоєнний період принесли Інституту широку відомість і високий авторитет як у Радянському Союзі, так і за його межами.

I коли 3 початком війни у вересні 1941 p. Інститут було евакуйовано до Уфи, його тематику було переорієнтовано відповідно до вимог війни. Новий напрям її було присвячено завданням допомоги фронту, зокрема тим завданням, які б сприяли найшвидшому виліковуванню поранених. У цих умовах під керівництвом академіка О. В. Палладіна було розроблено технологію одержання водорозчинного препарату вітаміну $K$, так званий вікасол, який знайшов широке застосування в шпиталях як кровоспинний засіб, що сприяв швидкому загоюванню ран.
Заявку «Способ прекращения кровотечений и ускорения заживления ран» на посвідчення про реєстрацію було подано ще у 1942 р., а посвідчення видано тільки у 1946 р. Справа в тому, що О. В. Палладін спочатку розробив технологію одержання аналога вітаміну $\mathrm{K}$, який він назвав вітаміном $\mathrm{K}_{3}$, але останній погано засвоювався в організмі. Тому пізніше було запропоновано синтез його водорозчинного сульфопохідного. Саме цей новий препарат і був названий вікасолом. Протягом короткого часу було вивчено фізикохімічні, біологічні і фізіологічні властивості нового препарату і пройдено клінічні випробування. Препарат вікасол легко засвоювався, його застосування per os обмежувало кровотечі в легенях, печінці та інших тканинах, попереджало паренхіматозні кровотечі за хірургічних втручань, кровотечі у разі поверхневих поранень, поранень шлунково-кишкового тракту, в гінекологічній практиці. Характерно те, що і процеси регенерації та загоювання ран за використання вікасолу значно прискорювались. На основі всебічного дослідження препарату було створено інструкцію з використання вікасолу у шпиталях, а Уфимський вітамінний завод розпочав його випуск у порошку і таблетках.

Пізніше вікасол став звичайним препаратом, який широко використовувався в терапевтичній, хірургічній і гінекологічній практиці.

І в повоєнні роки зусилля багатьох науковців Інституту було спрямовано на дослідження проблем, пов'язаних 3 вивченням механізмів 
зсідання крові. Піонером і першопрохідником у цих дослідженнях був видатний вчений зі світовим ім'ям, академік АН УРСР Володимир Олександрович Бєліцер.

Після повернення з евакуації у 1944 р. в Інституті біохімії АН України було створено лабораторію ферментів, яку в 1966 р. реорганізовано увідділ структуриі функціїбілка. Засновником як лабораторії, так і відділу був академік НАН України, професор В. О. Бєліцер, який очолював цю структуру понад 20 років $\mathrm{i}$ керував дослідженнями, присвяченими, в першу чергу, структурно-функиіональним властивостям протеїнів крові.

У цьому нарисі ми дуже коротко зупинимося на прикладних аспектах роботи відділу.

У 40-50-ті роки в літературі не було чіткого уявлення про нативний та денатурований стан протеїнів. Цим питанням і присвятили свої дослідження співробітники відділу під керівництвом В. О. Бєліцера. Внаслідок проведених досліджень сформульовано основні уявлення стосовно процесу денатурації протеїнів, під час якого відбувається розгортання поліпептидних ланцюгів, які в нативному стані певним чином згортаються, а їхні бічні групи в глобулі щільно упаковуються. Аналізуючи характер денатураційних перетворень, дослідники дійшли висновку, що нековалентні зв'язки, 3 якими пов'язана конформачійна організачія поліпептидного ланцюга, є взаємозалежними і між ними виявлено кооперативний зв'язок. Цей принцип кооперативності є характерним також для денатураційних змін протеїнової молекули. Базуючись на результатах цих робіт, співробітники відділу розробили методи одержання кровозамінників із протеїнів сироватки крові великої рогатої худоби (БК-8) та з колагену кісток. Саме денатурацією вдалося послабити видову специфічність протеїнів сироватки крові великої рогатої худоби, які використовувались у кровозаміннику. Таким чином, було створено новий препарат «Белковый кровезаменитель $5 K-8 »$, на який отримано авторське свідоцтво (В. О. Бєліцер, К. І. Коткова та ін., 1955 р.).

За участю К. І. Коткової також було розроблено і технологію виробництва БК-8 спочатку на Московському м'ясокомбінаті, а з 1963 р. - на новому спеціалізованому заводі Дарницького м'ясокомбінату (м. Київ).

Починаючи з 60 -х років минулого століття фундаментальні наукові розробки відділу

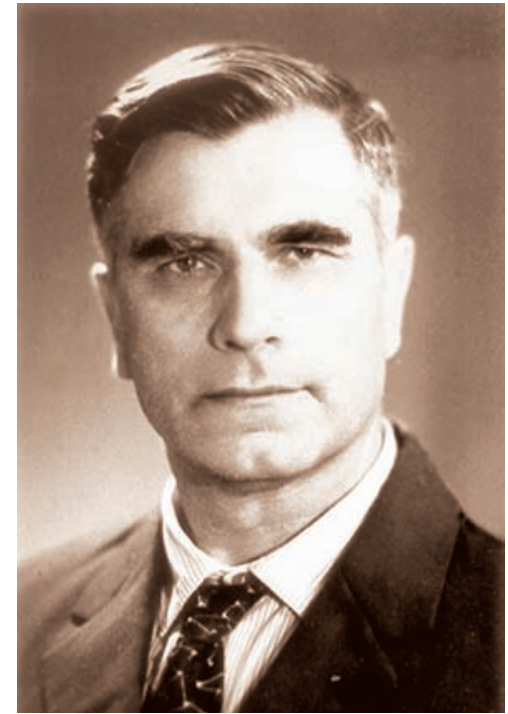

Академік АН УРСР В. О. Бєліцер (1906-1988)

структури і функції білка було спрямовано на дослідження прочесу зсідання крові, з'ясування механізмів перетворення фібриногену на фібрин, особливо заключного етапу цього процесу - самозбирання волокон фібрину. Із практичної точки зору дослідників цікавили біохімічні механізми утворення тромбів за серцево-судинних захворювань.

Підгрунтям для розвитку тромбозу у значної частини пацієнтів є тромбофілія, а саме виникнення схильності до посиленого тромбоутворення, тобто порушення в системі зсідання крові. Тромбофілію можуть спричинювати як генетично обумовлені, так і набуті чинники, в тому числі і метаболічні порушення. Тому вивчення факторів ризику тромботичних ускладнень у пацієнтів з ураженнями серцево-судинної системи, своєчасна діагностика тромбофілії та розробка індивідуальної програми профілактики тромбозів на ранніх етапах і зараз належить до актуальних медико-сочіальних завдань.

Під час дослідження перетворення фібриногену на фібрин В. О. Бєліцер показав, що утворення характерного фібринового згустку (тромбу) спостерігається лише в разі збереження нативного стану цього протеїну. З'ясування механізму перетворення фібриногену на фібрин стало можливим після встановлення двофазності процесу: модифікачії фібриногену ензимом тромбіном і наступної неензимної полімеризації (самозбирання) новоутвореного продукту. 
В. О. Бєліцеру і Є. Л. Ходоровій, одними 3 перших, вдалося чітко розділити ензиматичну та полімеризаційну фази процесу i висунути припущення стосовно істотного значення специфічних реактивних центрів для полімеризаиї фібрин-мономера. Вони вперше запропонували і обгрунтували гіпотезу утворення фібринового згустку - тромбу.

Пізніше (1969-1975 рр.) В. О. Бєліцер встановив роль іонів кальцію в стабілізації структури фібриногену і його фрагментів.

Практичним результатом цих досліджень стала низка розроблених авторами методів, зокрема: «Способ количественного определения продуктов деградации фибриногена и фибрина в моче» (В. О. Бєліцер, Т. В. Варецька, С. М. Цинкаловська та ін., 1976 р.) [1]; «Способ количественного определения фибриногена в плазме крови» (В. О. Бєліцер, Т. В. Варецька, Л. А. Царюк та ін., 1982 р.) [2]; «Способ определения растворимого фибрина в плазме крови» (Т. В. Варецька, В. О. Бєліцер, Л. І. Михаловська та інші, 1987 р.) [3]. Слід зазначити, що метод визначення продуктів розщеплення фібриногену і фібрину в сечі є унікальним для ранньої діагностики відторгнення пересадженої нирки, він також широко використовувався з метою диференційної діагностики різних серцево-судинних захворювань.

Починаючи з 70-х років минулого століття, вищенаведені розробки було впроваджено у практику медичних закладів України. Серед них слід згадати і методичні рекомендації під назвою «Методы определения фибриногена и компонентов фибринолиза плазмы крови человека», запропоновані Міністерству охорони здоров'я УРСР у 1983 р. В. О. Бєліцером Т. В. Варецькою, К. М. Веремеєнком.

У відділі також було розроблено метод визначення активності антитромбіну III в плазмі крові (В. О. Бєліцер, А. О. Мусялковська, Т. М. Платонова, Я. М. Єна, 1987 р.) [4]. Справа в тому, що антитромбін III (AT III) є основним фізіологічним інгібітором тромбіну та інших факторів зсідання крові. Він дуже швидко інактивує тромбін за участю свого активатора гепарину, і тому визначення його вмісту в плазмі крові є дуже важливим діагностичним тестом [5], а рівень AT III - показник стану системи зсідання крові. Недостатність його в організмі часто є причиною тромбозів.
Отже, фундаментальні дослідження механізмів регуляції самозбирання фібрину, його розщеплення в організмі, патологічних змін у системі гемостазу і пошук шляхів нормалізації функціонування цієї складної системи, проведені під керівництвом академіка В. О. Бєліцера, сприяли розробленню і впровадженню в медичну практику простих і надійних діагностичних методів, на які в свій час було одержано кілька авторських свідоцтв. А Володимира Олександровича Бєліцера можна вважати засновником вчення про систему гемостазу.

Започаткований ним науковий напрям досліджень процесів зсідання крові плідно продовжували i продовжують його учні $\mathrm{i}$ послідовники, пропонуючи результати своїх, майже ювелірних, фундаментальних досліджень для впровадження у медичну практику. Про це мова піде нижче як у цій статті, так і в наступній публікації.

Слід зазначити, що, починаючи 3 90-х років, в Інституті склались унікальні умови для успішного та комплексного вивчення протеїнів крові, зокрема протеїнів системи зсідання крові та фібринолізу, а також для створення технологій 3 виділення протеїнів крові та кількісного і якісного їх аналізу. Можна стверджувати, що на сьогодні три наукових відділи Інституту мають безпосередне відношення до цієї проблеми (тематики), зокрема: відділ структури і функції білка (керівник - чл.-кор. НАН України Е. В. Луговськой) традиційно вивчає полімеризацію фібрину (а також фібриноліз); відділ хімії та біохімії ферментів (керівник - д-р біол. наук Т. В. Гриненко) вивчає молекулярний механізм фібринолітичної системи крові та розробляє нові підходи до лікування тромбозів; відділ молекулярної імунології (керівник акад. С. В. Комісаренко), в якому вперше одержано моноклональні антитіла для з'ясування механізмів полімеризації фібрину та для імунодіагностики i, можливо, для імунотерапії порушень зсідання крові, і в якому розпочиналися дослідження полімеризації фібрину, коли там працював Е. В. Луговськой.

До речі, трохи теорії... Гемостаз - це захисна реакція організму, яка склалась еволюційно, i наслідком якої $\epsilon$ зупинка кровотечі під час ураження судини. Система гемостазу включає сукупність судинних, тромбоцитарних $i$ гуморальних компонентів плазми крові, 
що забезпечує швидку зупинку кровотечі у разі ураження судин. Нормальне функціонування гемостазу забезпечується динамічною рівновагою між прокоагулянтною, антикоагулянтною $i$ фібринолітичною ланками. Порушення балансу між вищенаведеними ланками спричинює внутрішньосудинне зсідання крові, яке може бути обумовлено тромбофілією (артеріальні, венозні та змішані тромбози), тромбоемболією тощо.

Функціонування ключових ланок системи гемостазу, їхня взаємодія і взаєморегуляція $\epsilon$ основою фізіологічного перебігу біохімічних процесів, спрямованих на підтримання рідкого стану крові. Тобто система зсідання крові $\epsilon$ однією з основних складових частин гемостазу.

Із біохімічної точки зору механізм зсідання крові іутворення згустку-це каскад послідовних ензиматичних реакцій за участю специфічних протеїнів - факторів системи зсідання крові. Кожний активований фактор активує наступний шляхом обмеженого протеолізу, перетворюючи проензим в ензим. Загальна кількість таких факторів - 13.

Саме дослідженням цих складних і важливих питань, пов'язаних із механізмом зсідання крові та його регуляції, вже декілька десятиліть займаються послідовники В. О. Бєліцера науковці відділу структури i функції білка Інституту біохімії ім. О. В. Палладіна НАН України.

Одержані у відділі теоретичні знання щодо функції окремих молекул протеїнів і механізмів регуляції процесів зсідання крові та фібринолізу відкривають нові можливості діагностики синдрому внутрішньосудинного зсідання крові, дозволяють вибрати чітко обгрунтовану терапію i контролювати ефективність лікування, а також сприяють розробленню технологій виділення (одержання) протеїнів - потенційних терапевтичних агентів.

Важливим інструментом для аналізу організації та функціонування біологічних систем, у тому числі і системи зсідання крові, в світовій практиці є отрути змій, які є сумішшю різних біологічно активних речовин. Деякі 3 них взаємодіють із компонентами системи гемостазу. Особливий інтерес викликають ензими - активатори та інгібітори, які впливають на різні етапи зсідання крові і фібринолізу. Залежно від специфічності дії вони поділяються на прокоагулянтні, антикоагулянтні та фібринолітичні.

Препарати, створені на основі отрути змій, мають широкий спектр протеїнів i пептидів, які впливають на компоненти системи гемостазу. Очищені препарати цих протеїнів можуть бути використані для наукових досліджень біологічних механізмів, які регулюють гемостаз. Слід констатувати, що деякі компоненти отрути змій використовуються не тільки для фундаментальних досліджень, але вже і в клінічній практиці, що є надзвичайно перспективним для широкого впровадження.

У 80-90-ті роки минулого століття властивостями отрути змій зацікавились співробітники відділу структури і функції білка, які розробили спосіб одержання з отрути щитомордника роду Agkistrodon ензимів, які виявляють коагуляціийну активність, і одержали на цей спосіб авторське свідоцтво (Т. П. Угарова, Л. В. Медведь, Д. А. Соловьев, С. В. Золотухин, 1987 р.) [6]. Так, під керівництвом канд. біол. наук Т. П. Угарової було виділено тромбіноподібний ензим 3 отрути щитомордника звичайного із Середньої Азії (Agkistrodon halys halys), на основі якого створено вітчизняний ензимний препарат, названий авторами анцистрон-H, а із щитомордника $A$. halys rhodostoma - анц̧истрон-В. Аничистрон-H, подібно до відомих у медичному світі рептилазі i анкроду, відщеплює від фібриногену тільки фібринопептид А, утворюючи фібрин дез $A A i$ фібриновий згусток. Він дуже високоспецифічно діє на фібриноген і не взаємодіє з іншими компонентами системи гемокоагуляції. Цей препарат із отрути щитомордника в значній кількості в ліофілізованому вигляді одержували у відділі структури i функції білка, задовольняючи не тільки власні потреби, але й потреби багатьох медичних установ колишнього СРСР.

Роботу в цьому напрямі було продовжено і в наступні роки (2000-2015 рр.). Вивчення властивостей ензимів, виділених із отрути змій Agkistrodon halys halys i Ehis multisguamatus, дозволило розширити арсенал діагностичних методів (Т. П. Угарова, Д. О. Соловйов, Т. М. Платонова, Н.І. Лукінова, О.В. Горницька). Так, зотрути щитомордника звичайного (Agkistrodon halys halys) співробітниками відділу під керівництвом докт. біол. наук, проф. Т. М. Платонової виділено і досліджено властивості чотирьох протеїнових препаратів: 
- тромбіноподібний ензим анцистрон-H, який рекомендовано використовувати для визначення вмісту фібриногену в плазмі крові під час гепаринотерапії, для одержання фібрину дез АA, а також для дослідження процесу самозгортання фібрину;

- фібриногенолітичний ензим, який можна використовувати для дослідження протеїн-протеїнових взаємодій, а також для дефібринування плазми крові за деяких патологій;

- активатор протеїну $C$, який можна використовувати для визначення рівня протеїну С в плазмі крові хворих;

- інгібітор агрегації тромбоцитів, властивості якого можуть потенційно допомогти в медичній практиці за розробки антитромботичних препаратів [7].

Використання ензиму коагуляції анцистрону-H з отрути щитомордника звичайного дало можливість авторам запропонувати спосіб визначення вмісту фібриногену в плазмі крові за гепаринотерапї̈ (Д. О. Соловйов, Т. М. Платонова, Т. П. Угарова та інші, 1992 р.) і одержати на нього авторське свідоцтво [8]. Цей спосіб може бути використаний для діагностики захворювань, які пов'язані з патологією системи гемостазу, одним із найважливіших показників якого $є$ вміст фібриногену в плазмі крові. Завданням цього винаходу була розробка способу, який дозволяє введенням анизистрону- $H$ визначати вміст фібриногену в плазмі крові навіть за наявності ендо- і екзогенних інгібіторів, а саме в умовах гепаринотерапіï. Справа в тому, що гепарин інгібує тромбін, тому в разі використання тромбіну одержані дані не відповідають дійсному вмісту фібриногену в крові, тоді як використання анщистрону-H дає можливість визначити його реальну концентрацію, навіть за наявності в плазмі крові продуктів деградації фібриногену/фібрину.

Переваги запропонованого методу порівняно з відомим аналогом було підтверджено також за дослідження крові хворих людей похилого віку з артеріальною гіпертензією, в яких спостерігалась висока активність інгібіторів, не пов'язаних із підвищенням рівня АT III i продуктів розщеплення фібрину/фібриногену.

Таким чином, переваги нового запропонованого методу порівняно $з$ відомими аналогами полягає в можливості одержання точних і об'єктивних результатів визначення вмісту фібриногену в присутності ендо- і екзогенних інгібіторів зсідання крові, наприклад, за гепаринотерапії, а також у спрощенні протоколу визначення цього показника системи гемостазу.

Властивості анцистрону-H було використано співробітниками відділу також за розробки діагностичного теста «анциистроновий час» для експрес-тестування стану системи гемокоагуляиії визначенням часу зсідання плазми крові (Т. М. Платонова, Н. І. Лукінова, О. О. Сушко та ін., 1993 р.). На цей спосіб одержано державний патент України [9]. Спосіб полягає в тому, що до інкубованої плазми в об’ємному співвідношенні $2: 1$ додають ензимний препарат анцистрон-H замість тромбіну або інших тромбіноподібних ензимів. У разі визначення часу зсідання крові вище нормального (30 2 сек) плазму розбавляють нейтральним буферним розчином у середньому в 1,5 раза і вдруге визначають час зсідання розведеної плазми, за яким тестують стан системи гемокоагуляиії, вимірюючи кількість фібриногену, наявність продуктів деградації фібриногену/фібрину та інгібіторів зсідання крові. Автори назвали метод «анцистроновий час» за аналогією 3 «тромбіновим часом», коли визначається час зсідання плазми за участю тромбіну; подовження часу зсідання крові свідчить про відхилення в системі гемокоагуляції. Тест «анциистроновий час» може бути використаний для діагностики захворювань, пов'язаних 3 порушеннями в системі зсідання крові і фібринолізу, які характеризуються змінами рівня фібриногену в плазмі, присутністю в ній продуктів деградації фібриногену/фібрину (ПДФ) та інгібіторів зсідання крові. Наявність в крові ПДФ та інгібіторів зсідання, гіпер- і гіпофібриногенемії $\epsilon$ важливим показником стану системи гемокоагуляції, що дає можливість виявити i передбачити хід розвитку хвороби, а також контролювати ефективність лікування.

Основним завданням цього винаходу було розроблення способу експрес-тестування стану системи гемокоагулящії, що одночасно забезпечує можливість дослідження інших параметрів коагуляції і підвищення точності тестування. Використання цього тесту в медичних установах дає економію кількості плазми крові людини у разі широкого діапазону досліджень і заміну імпортних ензимних препаратів вітчизняними. 
За розробки методу «аниистроновий час» було обстежено 68 осіб різного віку із серцевосудинними захворюваннями і 15 практично здорових осіб. Результати проведених досліджень показали, що тест «анцистроновий час» можна рекомендувати для дослідження плазми крові хворих у разі лікування гепарином, а також за використання екстракорпоральних методів лікування (гемосорбиія, гемодіаліз, плазмаферез тощо).

Характеризуючи запропонований тест «анщистроновий час», можна стверджувати, що він є високочутливим, відтворюваним та інформативним. Його використання одночасно 3 доступними та широко розповсюдженими в медицині підходами, а також за правильної інтерпретації даних дозволяє 3 високою точністю встановити низку порушень у системі гемокоагуляції за мінімальної затрати часу i плазми крові людини.

В отрутах змій, крім протеїнів - ензимів, виявлено також активатори $i$ інгібітори, які на різних етапах включаються в механізми функціонування системи гемостазу. До них належать активатори плазміногену, протеїну $C$, фактора Х зсідання крові і протромбіну, АT-III $i$ агрегаиії тромбоцитів. Особливо цікавим є активатор протеїну $C$ - інгібітора зсідання крові, нестача якого веде до тромбозів.

У відділі було розроблено спосіб виділення активатора протеїну $C$ з отрути щитомордника 3 метою тестування рівня протеїну С у плазмі крові людини (Н. І. Лукінова, Т. М. Платонова, О. О. Сушко, Д. О. Соловйов, 1994 р.); спосіб захищено державним патентом України [10]. $А \kappa-$ тиватор протеїну $C$ запропоновано виділяти 3 отрути щитомордника Agkistrodon halys halys розділенням розчиненої в буфері отрути на афінному сорбенті - блакитній агарозі, яка зв'язує протеїни, з яких потім виділяють ензим анцистрон-H. Незв'язану фракцію розділяють на іонообмінному носії - Q-сефарозі - 3 виділенням активатора протеїну C. Цей спосіб відрізняється від раніше запропонованих тим, що в ньому використовують Q-сефарозу як іонообмінний носій. Виділений у такий спосіб і ліофілізований препарат активатора протеїну $C$ зберігається не менше двох років i може використовуватись як для вивчення протеїну С в біохімічних дослідженнях, так і для визначення кількості протеїну С у плазмі крові людини в умовах клініки. Одержаний, таким чином, активатор протеїну $C$ є одноланцюговим глікопротеїном з Мм 32 кДа, який активує саме протеїн С людини.

Відомо, що рівень протеїну $C$ знижується у разі судинних захворювань, за цирозу і токсичних уражень печінки, нефротичного синдрому тощо. Тому визначення рівня протеїну С у плазмі крові $є$ важливим діагностичним показником. Концентрацію протеїну С у плазмі крові встановлюють різними методами. Завдяки точності, швидкості і простоті аналізу останнім часом у зарубіжній клінічній практиці застосовують методи, засновані на використанні активаторів протеїну C з отрути змій, $з$ якої, до речі, виділено цілу низку активаторів протеїну С. Але недоліком цих методів $€$ тривалість часу їхнього виділення, використання дефіцитних реактивів і багатоступінчатість.

Автори патенту порівнювали одержаний активатор протеїну $C$ із отрути щитомордника із закордонним фірмовим препаратом під назвою «Протак» за вмістом протеїну C у плазмі крові і показали, що обидва препарати дають практично однакові результати. Використання запропонованого авторами $а к-$ тиватора протеїну $C$ збільшує можливості клінічної діагностики патологій гемостазу: він виділяється 3 доступної сировини з використанням дешевих за собівартістю реактивів і обладнання, а тому може знайти широке застосування у повсякденній клінічній практиці. Водночас імпортний препарат «Протак» є досить дорогим і тому малодоступним для українських клінік.

Виділений авторами з отрути щитомордни$\kappa а$ звичайного активатор протеїну $C$ апробовано на плазмі крові понад 50 пацієнтів із різними патологіями: порушення сериево-судинної діяльності (інфаркт міокарда, стенокардія, артеріальна гіпертензія), абдомінальна кровотеча за виразкової хвороби, гестозів під час вагітності, нефритів, сепсису. В усіх випадках спостерігалась гіперактивація системи зсідання крові, яка веде до зниження рівня протеїну С. Тобто протеїн $C$ - ие протеїн швидкого реагування і визначення його вмісту має велике значення для дослідження балансу між потенціалом системи зсідання крові і інгібіторами. Зміна цієї рівноваги веде до накопичення у кровотоці фібрину і зниженню вмісту протеїну С.

Крім отрути щитомордника, співробітники відділу структури і функції білка зацікавились 
властивостями отрути ефи багатолускової середньоазійської (Echis multisquamatus). Якщо отрута щитомордника звичайного для людини не $є$ летальною, то отрута ефи дуже токсична. Після укусу ефи в людей порушуються процеси зсідання крові: спостерігаються падіння рівня фібриногену, тромбоичитопенія, підвищується активність протромбіну і кров не зсідається.

Співробітники відділу провели дослідження цієї отрути і виділили в очищеному стані три важливих препарати: ензим екамулін та інгібітори агрегаиії тромбоиитів і фібриногену.

Активатор протромбіну - екамулін 3 отрути ефи багатолускової було виділено ще у 1989 р., але детальніше охарактеризовано і досліджено його фізико-хімічні властивості у 1996 p. (Д. О. Соловйов, Т. М. Платонова, Т. П. Угарова) [11].

Екамулін $\in$ металопротеїназою 3 Мм 93 кДа, що містить 1 моль цинку на 1 моль протеїну. За механізмом дії на протромбін екамулін подібний до екарину - активатора протромбіну з отрути ефи пілолускової (Echis carinatus), але за фізико-хімічними властивостями він значно відрізняється від останнього. Під час інкубації 3 очищеним протромбіном екамулін активує протромбін до $\alpha$-тромбіну через стадію мезотромбіну в реакції, що не потребує присутності $\mathrm{Ca}^{2+}$, фосфоліпідів або інших кофакторів.

Виявилось, що в отруті ефu багатолускової міститься також низькомолекулярний протеїновий компонент, який здатен пригнічувати агрегацію тромбоцитів. Із використанням гель-хроматографії було одержано дезагрегатор тромбоцитів з Мм 6 кДа і встановлено, що він ефективно інгібує ADP-індуковану агрегацію тромбоцитів як у плазмі крові, так i тромбоцитів, позбавлених елементів плазми крові. Також було показано, що одержаний інгібітор не впливає на здатність тромбоцитів активуватись за дії тромбіну (Д. С. Корольова, В. О. Чернишенко, Т. М. Платонова, О. В. Горницька та ін., 2010-2014 рр.).

3 отрути ефи багатолускової співробітниками відділу також було одержано електрофоретично чистий поліпептид 3 Мм 33,2 кДа, який виявляв властивості фібриногенази. Препарат фібриногенази має триспрямовану дію - антикоагулянтну, антиагрегантну $i$ тромболітичну. По-перше, фібриногеназа частково гідролізує фібриноген, знижуючи його полімеризаційну здатність. Подруге, згусток, що містить такий фібрин(оген), значно швидше гідролізується плазміном. Тому фібриногеназа не лише прискорює руйнування фібринового згустку, але й сприяє руйнуванню розчинного фібрину. По-третє, фібриноген, який зазнав дії фібриногенази, меншою мірою підтримує агрегацію тромбоцитів (В. О. Чернишенко, Т. М. Платонова, О. В. Горницька та інші, 2010-2014 pp.).

Виділений у відділі препарат екамулін було запропоновано для тестування загального рівня протромбіну та виявлення його функиіонально неактивних форм у плазмі крові, що засвідчено державним патентом на винахід [12]. Авторами запропоновано спосіб, який відрізняється тим, що визначають так званий «екамуліновий індекс» - це відношення часу зсідання донорської плазми крові до часу зсідання досліджуваної, яке визначається в тесті 3 новим ензимом активатором протромбіну екамуліном 3 отрути ефи багатолускової. Потім порівнюють протромбіновий i екамуліновий індекси: їх збіг свідчить про відсутність функціонально неактивних форм протромбіну; в разі, коли екамуліновий індекс вище протромбінового, можна кількісно визначити вміст функціонально неактивних форм протромбіну в плазмі. При цьому чим більша різниця між індексами, тим вища концентрація протромбіну 1 , який є маркером синдрому внутрішньосудинного зсідання крові (ВЗК).

Вміст протромбіну в крові значно змінюється залежно від статі, віку і стану здоров'я. Істотно змінюється вміст протромбіну за захворювань різної етіології: $K$-залежних гіповітамінозах, інфекиійних захворювань, у разі проведення екстракорпоральних методів лікування (гемосорбиія, плазмаферез тощо).

Поява в кровотоці таких функціонально неактивних форм протромбіну, як декарбоксильований протромбін і фрагменти протромбіну (фрагмент $1+2$ і протромбін 1) свідчить про порушення в системі зсідання крові. У вітчизняній клінічній практиці тоді ще не існувало способів виявлення функціонально неактивних форм протромбіну в плазмі крові.

Для визначення протромбіну широке використання в клінічній практиці має тест «протромбіновий час». Він дає можливість 
визначати час зсідання плазми крові за участю екзогенного тромбопластину $i$ в присутності іонів $C a$. За його допомогою можна визначити тільки вміст нормального протромбіну, але він не чутливий до його декарбоксильованої форми. Крім того, результати цього тесту потребують ретельної стандартизації і високої якості препаратів тромбопластину.

Водночас екамулін - ензим виділений співробітниками відділу структури і функції білка з отрути ефи багатолускової - перетворює протромбін на $\alpha$-тромбін через стадію мезотромбіну i не потребує наявності іонів $\mathrm{Ca}$, фосфоліпідів або інших кофакторів. За таким самим механізмом цей ензим активує i протромбін 1. Екамулін - стабільний ензим, він високоспецифічний до протромбіну і при цьому не взаємодіє 3 іншими компонентами гемокоагуляції. Тому його використання в клінічній практиці має цілу низку переваг.

Таким чином, авторами винаходу розроблено тест на визначення загального рівня протромбіну і виявлення його функціонально неактивних форм із використанням ензимного препарату - екамуліну - активатора протромбіну. Тест було опрацьовано на плазмі практично здорових людей і хворих на гіпертонічну хворобу (артеріальну гіпертензію). Одержані результати підтвердили високу точність тесту і його відтворюваність. Порівняння даних двох тестів - «протромбінового» і «екамулінового» часу зсідання плазми крові дає можливість охарактеризувати стан системи зсідання крові, виявити функціонально неактивні форми протромбіну, які є маркерами тромботичних ускладнень низки захворювань.

Екамулін було використано і в запропонованому співробітниками відділу способі для контролю ефективності лікування і профілактики тромбозів антикоагулянтами непрямої дї [13] Сутність цього винаходу полягає в порівнянні результатів активації протромбіну плазми крові тромбопластином і екамуліном із використанням хромогенного субстрату S2238. Це дозволяє визначити вміст декарбоксильованого протромбіну плазми крові за рівнем екамуліново-протромбінового відношення.

Справа в тому, що за активації протромбіну плазми крові тромбопластином амідолітична активність тромбіну відповідає вмісту лише функціонально активного протромбіну. А за активації протромбіну плазми крові екамуліном амідолітична активність тромбіну вказує на $c y$ марний рівень функціонально активного і декарбоксильованого протромбіну.

Перевагами запропонованої авторами тестсистеми контролю ефективності лікування антикоагулянтами непрямої дії є:

- одержання інформації про вміст декарбоксильованого протромбіну в плазмі крові, поява якого є безпосереднім наслідком впливу антикоагулянтів непрямої дії;

- використання екамуліну забезпечує високу точність і відтворюваність результатів тесту, оскільки він безпосередньо активує протромбін, а не його функціонально неактивні форми;

- використання тромбінспецифічного хромогенного субстрату для визначення вмісту тромбіну, що утворюється за дії активаторів, нівелює вплив екзогенних i ендогенних інгібіторів системи гемостазу на результати тесту.

Крім того, перевагами цієї тест-системи є: швидкість виконання аналізу (не більше 10 хв); кількість аналізів із використанням однієї тестсистеми дорівнює 40; відсутність вітчизняних і закордонних аналогів.

Разом зі співробітниками Національного університету біоресурсів і природокористування України (В. О. Чернишенко, Т. М. Платонова, Д. О. Мельничук та ін., 2011 р.) було запропоновано використання екамуліну також для розробки способу контролю за функиіональним станом печінки та ефективністю лікувальних препаратів за гепатиту [14].

Справа в тому, що активність ензимів системи гемостазу безпосередньо пов'язана 3 функціональним станом печінки, оскільки гепатоцити $є$ основним місцем синтезу протеїнів системи зсідання крові. Під час захворювань печінки знижується не тільки швидкість синтезу протеїнів, але й посттрансляційне карбоксилювання в них залишків глутамінової кислоти. Такі некарбоксильовані форми вітамін-К-залежних протеїнів називають PIVKA-протеїнами (протеїни, що утворюються за відсутності вітаміну К). Вони нездатні утворювати ензимні комплекси на поверхні ліпідного шару біомембран у присутності іонів кальцію i втрачають здатність виконувати відповідні функції в системі зсідання крові (як тут не згадати започатковані ще у 40-ві роки 
минулого століття роботи О. В. Палладіна "Способ прекращения кровотечений и ускорения зажсивления ран» на основі застосування водорозчинного препарату вітаміну K!). Накопичення функціонально неактивних форм вітамінК-залежних протеїнів системи зсідання крові за розвитку патології печінки призводить до зниження прокоагулянтного потенціалу цієї системи та може супроводжуватись виникненням кровотеч. Тому контроль за показниками системи гемостазу є важливим етапом для визначення ступеня порушення протеїнсинтезуючої функції печінки за гепатопатологій і ефективності дії лікувальних препаратів.

Запропонований авторами спосіб полягає у визначенні в плазмі крові функціонально неактивних форм протромбіну (PIVKA-тромбін) за різницею протромбінового і екамулінового тестів, що розраховують за відношенням амідолітичної активності досліджуваної плазми крові до амідолітичної активності контрольної плазми крові; цей показник є маркером порушень протеїнсинтезуючої функції гепатоцитів. А використання тромбінспецифічного хромогенного субстрату дозволяє максимально, незалежно від дії екзогенних і ендогенних інгібіторів системи зсідання крові фіксувати відновлення функцій печінки за вмістом функціонально активних вітамін-К-залежних протеїнів.

Таким чином, використання способу визначення співвідношення функціонально активних і неактивних форм протромбіну дозволяє здійснювати безпосередній контроль за відновленням синтезу функціонально активних вітамін-К-залежних протеїнів у печінці. Цей тест забезпечує високу точність і відтворюваність результатів, не має вітчизняних і закордонних аналогів.

Використання активатора протромбіну екамуліну - з отрути ефи багатолускової було запропоновано і для прогнозування тромботичних ускладнень у разі регматогенного відшарування сітківки ока (О. В. Горницька, Т. М. Платонова, І. П. Метеліцина, 2001 р.). Розвиток різних офтальмопатологій, в тому числі і патологій очного дна, супроводжується змінами вмісту та/ або активності факторів зсідання крові, які знаходяться в тканинах і рідинах інтактного ока людини. Патологія сітківки ока характеризується гіперкоагуляційними порушеннями в крові, накопиченням проензимів системи зсідання крові та зниженням вмісту їх інгібіторів.
Автори винаходу [15] запропонували спосіб прогнозування тромботичних ускладнень за відшарування сітківки ока, який включає використання активатора протромбіну - екамуліну для визначення часу зсідання плазми $\mathrm{i}$ відношення індексу часу зсідання плазми крові донорів до часу зсідання їі суміші із субретинальною рідиною ока.

Аналіз проведених досліджень показав, що запропонований спосіб є специфічним, високочутливим i спрощує виявлення вмісту протромбіну в субретинальній рідині ока. Оскільки екамулін безпосередньо активує тільки протромбін, то використання цього ензиму-активатора забезпечує високу точність i відтворюваність результатів.

Ще у 1998 р. співробітниками відділу було запропоновано спосіб прогнозування тромботичних ускладнень в акушерській практичі (С. М. Макогоненко, Т. М. Платонова, В. Я. Голота, М. Ш. Гамісонія), захищений патентом на винахід [16]. Автори пропонують крім лабораторних тестів на рівень фібриногену i протромбіновий індекс додатково проводити тести на розчинний фібрин, вміст фактора $X$, антитромбіну III $i$ протеїну C. Застосування комплексу наведених тестів дозволяє об'єктивно оцінити стан прокоагулянтної ланки системи гемостазу, визначити вміст фізіологічних інгібіторів і виявити маркер тромбінемії - розчинний фібрин - в акушерській практиці.

У відділі було також розроблено спосіб прогнозування тромботичних ускладнень за розвитку патологій внутрішньосудинного зсідання крові (О. М. Савчук, Є. М. Краснобрижа, Т. М. Чернишенко, Т. М. Платонова, 2002 р.), який захищено державним патентом на винахід [17]. Він включає проведення лабораторних тестів, за результатами яких визначають індекс, що характеризує систему зсідання крові та фібринолізу. В цьому способі визначають індекс тромботичного ускладнення за співвідношенням вмісту розчинного фібрину (маркера тромбінемії) до активності тканинного активатора плазміногену або часу загального лізису еуглобулінів; розрахунки проводять визначеною авторами формулою.

Запропонований спосіб дозволяє визначити співвідношення ступеня активації системи зсідання і потенціалу системи фібринолізу для прогнозування тромботичних ускладнень за розвитку внутрішньосудинного зсідання крові. 
Для потреб сучасної біотехнології у відділі структури і функції білка було розроблено спосіб стабілізації водно-сольового розчину тромбіну [18]. Він полягає в тому, що як стабілізуючі реагенти автори використовували $D L$-лізин або L-глутамінову кислоту. Ці реагенти стабілізують тромбін завдяки їх взаємодії 3 реактивними центрами тромбіну з утворенням сполуки типу ензим - субстрат, що гальмує процес його автолізу.

Водно-сольові розчини тромбіну мають переваги порівняно 3 ліофілізованими препаратами, оскільки вони не потребують додаткового розведення й необхідності підбирати кількість розчинника безпосередньо перед ін'єкціями, тобто виконувати ще додаткову процедуру в разі використання їх у медицині.

Друга біотехнологічна розробка співробітників відділу також стосувалась одержання стабілізованого розчину $\alpha$-тромбіну (М. В. Колодзейська, Є. М. Макогоненко, Г. Л. Волков, 2004 р., державний патент на винахід від 2006 р.) [19]. Автори пропонують використовувати як стабілізатор розчину $\alpha$-тромбіну органічний ліганд іонної природи роселін, який не тільки діє на сольватну оболонку молекули тромбіну, а також зв’язується 3 активним центром тромбіну.

Підводячи риску під цією частиною багаторічних фундаментальних і прикладних досліджень протеїнів системи зсідання крові, започаткованих корифеями світової біохімії О. В. Палладіним і В. О. Бєліцером, слід зазначити, що співробітниками відділу структури і функції білка створено сучасні уявлення про систему гемостазу, які узагальнено в монографії [20], розроблено значну кількість діагностичних методів, способів і тестів для оцінювання стану системи гемостазу, які апробовано в багатьох клініках і на великій кількості пацієнтів, включно із захворюваннями серцево-судинної системи, з урологічною патологією, за діабету, абдомінальних кровотечах у разі виразки шлунка, ускладненнях у вагітних жінок (кесарів розтин), у людей похилого віку, пацієнтів із тяжкими опіками, а також у ліквідаторів аварії на Чорнобильській атомній станції. Для кожної патології виявлено специфічні особливості порушень у системі гемостазу і розроблено певний алгоритм діагностики [21]. Запропоновані діагностичні методи характеризуються високою чутливістю, специфічністю, відтворюваністю та інформативністю. Більш того, застосування їх у клінічних лабораторіях не потребує додаткового обладнання і водночас максимально різнобічно характеризує стан системи гемостазу у хворих людей. Дуже важливим $є$ і те, що аналогів цим тестам в Україні немає. Тому на основі одержаних даних Міністерством охорони здоров'я України підготовлено методичні рекомендації $[22,23]$.

У наступній публікації ми детальніше зупинимося на фундаментальних дослідженнях молекулярних механізмів полімеризації/ деполімеризації фібрину i на розробці імунодіагностичних тест-систем для оцінки системи гемостазу і прогнозування тромбозів на основі використання моноклональних антитіл.

\section{References}

1. A.c. $520543 \mathrm{SU}, 2 \mathrm{G} 01 \mathrm{~N}$ 33/16. Способ количественного определения продуктов деградации фибриногена и фибрина в моче / В.А. Белицер, Т.В. Варецкая, С.Н. Цынкаловская, Л.А. Царюк, Я.М. Ена, Г.А. Белицкая. - Заявл. 22.05.74. Опубл. 15.07.1976. Бюл. № 25.

2. А.c. $978862 \mathrm{SU}, 3 \mathrm{~A} 61 \mathrm{KN}$ 35/16. Способ количественного определения фибриногена в плазме крови / В.А. Белицер, Т.В. Варецкая, Л.А. Царюк, Ю.П. Бутылин, О.А. Буняк. Заявл. 03.03.1980. Опубл. 07.12.1982. Бюл. № 45 .

3. A.c.1354115 SU, 4 G $01 \mathrm{~N}$ 33/50. Способ определения растворимого фибрина в плазме крови / Т.В. Варецкая, В.А. Белицер, Л.И. Михаловская, Я.М. Ена, Л.А. Дидковская. - Заявл. 22.03. 1985. Опубл. 23.11.1987. Бюл. № 43.

4. Белицер В. А., Мусялковская А. А., Платонова Т. Н., Ена Я. М. Определение активности антитромбина III в плазме крови. Лаб. дело. 1987; (4): 255-259.

5. Белицер В. А., Мусялковская А. А., Платонова Т. Н., Ена Я. М. Антитромбин III. Функциональная роль и методы определения. Вопросы мед. химии. 1987; (4): 8-15.

6. А.c. № 1476649 SU, 4 A6 K № 35/58. Способ получения ферментов, обладающих коагулирующей активностью из яда змей рода Agkistrodon / Т.П. Угарова, Л.В. Медведь, Д.А. Соловьев, С.В. Золотухин; заявник 
i патентовласник Інститут біохімії ім. O.В. Палладіна Академії наук УРСР i Трипільський біохімічний завод. - Заявл. 20.07.1987. - ДСП, 1989.

7. Горницкая О. В., Платонова Т. Н., Волков Г. Л. Ферменты змеиных ядов. Укр. біохім. журн. 2003; 75(3): 22-32.

8. Пат. 10374 Україна UA, A G 01 № 33/49; А 61 K 35/16. Спосіб визначення вмісту фібриногену в плазмі крові при гепаринотерапії / Соловйов Д.О., Платонова Т.М., Сушко О.О., Єна Я.М., Угарова Т.П.; заявник і патентовласник Інститут біохімії ім. О.В. Палладіна НАН України. - № 93020162; заявл. 11.12.1992; опубл. 25.12.1996, Бюл. № 4.

9. Пат. 14516 Україна UA, 6 G01 № 33/86. Спосіб експрес-тестування стану системи гемокоагуляції за допомогою визначення часу зсідання плазми / Платонова Т.М., Лукінова H.I., Сушко О.О., Соловйов Д.О., Угарова Т.П.; заявник i патентовласник Інститут біохімії ім. О.В. Палладіна НАН України. - № 93007566; заявл. 27.12.1993; опубл. 28.02.2000, Бюл. № 1.

10. Пат. 17056 Україна UA, 6 C 12 № 9/50, А 61 К 35/38. Спосіб виділення активатора протеїну C 3 отрути щитомордника для тестування рівня протеїну С в плазмі крові людини / Лукінова Н.I., Платонова Т.М., Сушко О.О., Соловйов Д.О.; заявник i патентовласник Інститут біохімії ім. О.В. Палладіна НАН України. - № 94076235; заявл. 14.07.1994; опубл. 15.09.2000, Бюл. № 4.

11. Соловьев Д. А., Платонова Т. Н., Угарова Т. П. Выделение и характеристика экамулина активатора протромбина из яда эфы многочешуйчатой (Echis multisguamatus). Биохимия. 1996; 61(6): 1094-1105.

12. Пат. 14580 А Україна UA, G 01 № 33/86. Спосіб тестування загального рівня протромбіну та виявлення його функціонально неактивних форм у плазмі крові / Платонова Т.М., Сушко О.О., Петров О.В., Соловйов Д.О.; заявник і патентовласник Інститут біохімії ім. О.В. Палладіна НАН України. № 94076234; заявл. 14.07.1994; опубл. 20.01.1997 (15.09.2000), Бюл. № 4.

13.Пат. № 86856 Україна UA, МПК (2009); G 01 № 33/50; А 61 В 5/00. Тест-система та спосіб контролю ефективності лікування та профілактики тромбозів антикоагулянтами непрямої дії / Корольова Д.С., Чернишенко Т.М., Платонова Т.М., Волков Г.Л., Дєєв В.А., Куповська C.I.; заявник i патентовласник Інститут біохімії ім. О.В. Палладіна НАН України. - 200708173; заявл. 18.07.2007; опубл. 25.05.2009, Бюл. № 10.

14. Пат. № 99046 Україна UA, МПК (2012, 01); А 61 В 5/00; G 01 № 33/49 (2006, 01). Спосіб контролю за функціональним станом печінки та ефективністю лікувальних препаратів при гепатиті / Мельничук Д.О., Грищенко В.А., Томчук В.А., Литвиненко О.М., Чернишенко В.О., Грищук В.I., Платонова Т.М.; заявник і патентовласник Національний університет біоресурсів i природокористування України. - № а 201102924; заявл. 10.10.2011; опубл. 10.07.2012, Бюл. № 13.

15. Пат. № 43248 Україна UA, А 7 А 61 В 5/145. Спосіб прогнозування тромботичних ускладнень при регматогенному відшаруванні сітківки ока / Горницька О.В., Платонова T.M., Метелицина І.П.; заявник i патентовласник Інститут біохімії ім. О.В. Палладіна НАН України. № 2001042869; заявл. 26.04.2001; опубл. 15.11.2001, Бюл. № 10 .

16. Пат. № 31304 А Україна UA, А 6 G 01 № 33/86. Спосіб прогнозування тромботичних ускладнень в акушерській практиці / Голота В.Я., Гамісонія М.Ш., Макогоненко С.М., Платонова T.М.; заявник i патентовласник Інститут біохімї ім. О.В. Палладіна НАН України. - № 98074200; заявл. 31.07.1998; опубл. 15.12.2000, Бюл. № 7.

17. Пат. № 52215 Україна UA, 7 G 01 № 33/48, 33/86. Спосіб прогнозування тромботичних ускладнень при розвитку патологій внутрішньосудинного згортання крові / Савчук O.M., Краснобрижа Є.M., Чернишенко Т.М., Платонова Т.М.; заявник i патентовласник Інститут біохімії ім. О.В.ПалладінаНАНУкраїни.-№2002032146; заявл. 18.03.002; опубл. 15.08.2005, Бюл. № 8 .

18. Пат. № 73399 Україна UA, С 2; 7 C 12 № 9/74; А 61 К 35/16. Спосіб стабілізації водно-сольового розчину тромбіну / Колодзейська М.В., Макогоненко Є.М., Волков Г.Л.; заявник i патентовласник Інститут біохімії ім. О.В. Палладіна НАН 
України. - № 2003076277; заявл. 07.07.2003; опубл. 15.07.2005, Бюл. № 7.

19. Пат. № 76270 Україна UA, С 2 МПК (2006); C 12 № 9/74; A 61 К 35/16; G 01 № 33/50. Стабілізований розчин $\alpha$-тромбіну / Колодзейська М.В., Макогоненко С.М., Волков Г.Л.; заявник i патентовласник Інститут біохімії ім. О.В. Палладіна НАН України. - № 20040705505; заявл. 08.07.2004; опубл. 17.07.2006, Бюл. № 7.

20. Волков Г. Л., Платонова Т. Н., Савчук А. Н., Горницкая О. В., Чернышенко Т. М., Краснобрижая Е. Н. Современные представления о системе гемостаза. К.: Наукова думка, 2005. 296 с.

21. Платонова Т. М., Чернишенко Т. М., Савчук О. М., Горницька О. В., Соко- ловська Л. І., Гамісонія М. Ш., Макогоненко Є. М. Лабораторна діагностика стану системи гемостазу. Укр. біохім. журн. 2000; 72(6): 67-73.

22. Токар А. В., Макогоненко Є. М., Платонова Т. М. Сучасні методи лабораторної діагностики внутрішньосудинного мікрозсідання крові: метод. рекомендації. МО3 АМНУ, Укр. центр наук. мед. інформ. та патент.-ліценз. роботи. К., 1994. 22 с.

23. Клініко-лабораторна діагностика тромбофілій: метод. рекомендації / Н. В. Заічко, Ю. О. Безсмертний, Т. М. Платонова, Т. М. Чернишенко. Вінниця: НДІ РІ ВНМУ ім. М. І. Пирогова, 2009. 32 с.

Отримано 15.03.2016 